\title{
Might Diversity also be Ontological? Considering Heidegger, Spinoza and Indigeneity in Educative Practice
}

\author{
Podría Considerarse el Concepto de Diversidad \\ como Ontológico? Analisis de Heidegger, \\ Spinoza, y la Indigeneidad en \\ la Práctica Educativa
}

\section{La Diversité Pourrait-elle aussi être Ontologique? Heidegger, Spinoza et I'Indigénat dans la Pratique Éducative}

\section{Chris Beeman}

Queen's University

\section{Sean Blenkinsop}

Simon Fraser University

\section{ABSTRACT}

We argue that the words and work of certain Teme Augama Anishinaabe elders point to another state of being, a different ontological position, from the one most broadly expressed in modern western culture and in its schools. We propose to call this state attentive receptivity. We invoke Spinoza and Heidegger to support this position. While leaving the door open for still other states of being, we sketch in some key conditions and qualities of attentive receptivity, including an interdependence with the more-than-human world. We argue that attentive receptivity can be seen as a different ontological position because of fundamental differences in what is enacted as self, place, community, and environment. In a supporting argument, we also think that different ways of knowing imply or point toward, though they do not explicitly prove, at least one different way of being. Through this reflexively coupled loop of ontology and epistemology we conclude by suggesting that if educational institutions wish to seriously address issues of diversity, they would do well to consider novel educative approaches that incorporate an understanding, appreciation and accommodation of diverse ontological positions.

Key words: diversity, indigenous, ontology, epistemology, ecology, Heidegger, Spinoza. 


\section{RESUMEN}

Nosotros defendemosquelas palabras y trabajos realizados porlos ancianos "Augama Anishinaabe" suponen otra forma del ser, una posición ontológica distinta de la habitualmente expresada en la cultura occidental moderna y sus escuelas. Proponemos llamar a este estado "receptividad atenta." Para fundamentar esta expresión recurrimos a autores como Spinoza y Heidegger. Los principales rasgos de esta "receptividad atenta" Incluyen la interdependencia con el mundo no humano. La "receptividad atenta" puede ser vista como un ontología alternativa, debido a las diferencias fundamentales en torno al lugar que juegan en ella la comunidad y el medioambiente. Igualmente creemos que las diferentes formas de conocimiento existentes también apuntan a una diferente forma de ser. A través de este bucle compuesto de reflexiones ontológicas y epistemológicas, sugerimos que si las instituciones educativas desean abordar seriamente las cuestiones de la diversidad, deberían incluir en los nuevos enfoques educativos asuntos relativos a la comprensión, el aprecio y la inclusión de las diversas posiciones ontológicas.

Descriptores: diversidad, indígenas, ontología, epistemología, ecología, Heidegger, Spinoza.

\section{RÉSUMÉ}

En considérant le travail et les paroles de certains Anciens anishinaabés, de Heidegger et de Spinoza, nous soutenons qu'ils indiquent un autre état d'être, une position ontologique différente de celle qui est généralement exprimée dans la culture orientale et dans ses écoles. Nous appelons cet état réceptivité attentive. Tout en laissant la porte ouverte à encore d'autres états d'être, nous indiquons certaines conditions clés et certaines qualités, y compris une interdépendance avec le monde supra humain. Nous affirmons que la condition de réceptivité attentive peut être vue comme une position ontologique différente à cause de différences fondamentales en ce qui est compris et représenté comme le moi, le lieu, la communauté et le milieu. Nous pensons aussi que les arguments présentés en faveur de manières différentes de connaître supposent une autre manière d'être. Par cette boucle d'ontologie et d'épistémologie associées réflexivement, nous concluons en suggérant que l'éducation, si elle est sérieuse au sujet de la diversité, ferait bien de considérer à la fois l'ontologie et l'épistémologie en créant une éducation vraiment diverse.

Mots-clés : ontologie, indigène, diversité, épistémologie, Heidegger, Spinoza.

W ture-Modwestcult ${ }^{1}$ for short - is currently the dominant one on Earth. Amongst other things, it presupposes the primacy and centrality of the individual human and situates humankind over and above all else. This hubris-laden position has allowed it to reckon that it can know, plan for, and use what it calls the resources of nature without attention to the costs to a wider ecosphere. We think that this eroding effect of Modwestcult is also reflected in its increasing homogenization, in spite of superficial attention to diversity. ${ }^{2}$ Of most import for this paper is the erosion of ontological diversity. In addition to what we believe is inherently desirable in diversity, we think that certain ways of being are also linked to a variety of knowledges. Thus, a diminishing of ontological diversity may also reduce breadth of knowledge.

By ontological diversity we do not mean to refer to isolable factors such as "cultural," "linguistic," or "ethical" difference, nor to any other category of difference that currently exists within the scheduled castes of difference, as crucial as these are to understand. We mean to highlight that being itself, and the very concept of what being and the self are, must underlie the aforementioned descriptive labels which are themselves a product of a particular ontological positioning. As our argument progresses, 
it will suggest that the understanding of any of these concepts is directly related to the underlying ontological position. Thus, if what constitutes being changes, then concepts such as the self, place, community or culture change in concert with each other depending upon where the line is drawn. When an Anishinaabe Elder understands and enacts the self as not stopping at the skin/air interface, but extending into a larger sphere of interaction and interdependence with the more-than-human-world, then this is, we argue, a different ontological position from which to understand the world. This will affect other concepts related to being such as place, community, environment and nature.

By proposing to investigate ontological diversity in people, we offer a response to the ongoing process of vilifying and marginalizing those who are not recognized as being fully human or whose humanness is narrowed, mostly through ignorance and neglect. ${ }^{3}$ A more insidious problem that results from the loss of ontological diversity is the disappearance of the range of possibilities available to being in the first place. Add to this the epistemological implications of diverse ontologies with respect to knowledge, knowers, and meaning-making and the educational links become quite clear. We think that in conjunction with its political and military branches Modwestcult is engaging in a much less obvious form of colonization - that is over the territory of what kind of being is permitted to be recognized as human. Before continuing, perhaps an introductory example of what we refer to might be useful.

When Anishinaabe Elder Michael Paul spoke in a documentary film (Beeman, 2004) about protecting a spirit place from the threat of clear-cut forestry, he said the following:

being in touch is ${ }^{4}$
waking up in the morning
[looks points]
and you walk out
walk down to the beach there
look around

I don't know

I look

I look out there

and I say

"good morning"

I'm talking to people that have been here

- gone-

ones that are still coming yet

what they going to bring?...

and you try to get in touch...

try to get in touch with them there 


\author{
if you're really feel good \\ you'll bend down \\ and you'll feel the ground \\ feel the water \\ touch the leaves
}

We enjoy this passage because it effortlessly evokes the qualities of a person who is infused with place. Michael Paul is an elder of the Teme Augama Anishinaabe band. He identifies himself with one of the last families "to really live off the land" in the area. ${ }^{5}$ His words express an active-being connection, as well as a kind of knowing, at times overtly discursive, with the earth, water, living things, and the ancestors - "people that have been here/-gone-/ones that are still coming yet" — as real beings in the place that is known now. So we see a potential shift in the position of self, being, and knowing as well as an historical overlay that is the antithesis of the intensely temporary and disconnected quality of Modwestcult. ${ }^{6}$

The reason we bring in this brief example now is for you to begin to consider it, as we do, as an instance that might not be merely about yet another variation of the being that infuses most of us who write and read papers like this one. This example hints that it is dangerous to see other peoples' practices as simply different cultural adaptations of the same us. We think that Modwestcult makes a similar mistake in interpreting diversity. In Modwestcult's view of diversity, however different people might seem to be, they are based on a limited conception of what it is to be a person. But what if there really are different kinds of being human?

\title{
Attentive Receptivity and Meander Knowing
}

In answering the above question, we must be clear that for our argument to work there is a difference between "different modes of being human" and "different expressions of humanity." For example, one might wonder if Michael Paul is operating out of a different mode, state or way of being, or expressing a variation on the same mode that we in Modwestcult regularly enact. Our claim is that if one or more other states of being exists then signs such as differences in those ideas that are related to being (e.g. place, self, community, etc.) or related to ways knowing (e.g. knowledge, knower, meaning-making) will become apparent. This first sort of evidence-the residue left in intellectual concepts as it were - might be considered circumstantial. We consider it circumstantial because intellectual ideas may reflect ontological change but are not themselves ontological change.

In addition to the above-noted evidence, the second kind, for which we provide phenomenal observations, is direct. Beeman's doctoral research focused on one alternative mode of being, an accompanying epistemological state, and styles of learning suited to these (Beeman, 2006). In working with Anishinaabe elders, he found that one particular state of being was repeatedly - though obliquely - referred to. This is the state we call attentive receptivity. He called attentive receptivity a "state of being" and not merely an alternative emotional or intellectual expression, because 
it is achieved only in the context of a certain life lived. This is a life lived in deep interdependence with place such that the continuation of one's life and the health of the ecosystem are inextricably linked. In this state, consciously assuring, through long-term labour, the meeting one's life needs is not a choice but an integral aspect of being. And the assuring of one's own life needs also contribute towards the long-term health of the ecosystem, on which one's long-term well-being relies. The significance of this state of being for this discussion is that it not only offers these conditions of ontological difference whereby what self is changes but it also is a state in which the borders of the self relax and become permeable with the more-than-human world. Couple this with an epistemological parallel we calling meander knowing and we think this becomes significant for education per se because it poses the question that if public education systems are really concerned about diversity, what is to be done about this significant way of being, differently?

Attentive receptivity is thus defined as an enacted state of being that satisfies the above conditions, in which what Modwestcult limitedly calls the person, consciously assures its continued existence in conjunction with the overall health of the ecosystem. Its accompanying conceptual qualities include: less will-directedness in knowing, an attunement to what lies outside Modwestcult's definition of the self, and a lateral expansiveness of awareness as one becomes the canvas upon which the painting of co-created ideation - and being - occurs. While we think that these qualities and others may occur in other states of being, we do not know this. For the purposes of this paper we are interested in these qualities only as they emerge from a kind of life lived such that person and place co-create meaningful existence- that is, the ontological enactment of attentive receptivity.

Meander knowing is the name we give to the kinds of knowing - the epistemological accompaniment - to the ontological state of attentive receptivity. This is the kind of knowing that occurs in synchrony with the above qualities. It is related to the intuitive kind of knowing that has long been identified in educational literature, (Noddings and Shore, 1984) and to research into creativity, the arts, and the environment.

In order to build upon our argument, and before going back to the words of the Anishinaabe Elders, we will attempt to situate this idea within the opus of Western philosophy, not a necessary condition for acceptance, but another chapter in the story. And so we turn to two very different philosophers, Spinoza and Heidegger, whose writings, despite their differences, may be interpreted as supporting this insight.

\section{Spinoza and Heidegger}

Both Spinoza and Heidegger referred to other ways of knowing. In the case of Spinoza, his third way of knowing included the capacity to know apparently analytically and synthetically, at once (Shirley, 2002). In the case of Heidegger, the primordial way of knowing is available to the Dasein who is engaged in examining her own existence after she has passed beyond merely instrumental concerns. While these philosophers' identification of different ways of knowing is not proof that they 
presupposed a different way of being associated with these ways of knowing, we think that the context of their larger work makes a convincing argument.

In Spinoza's cosmology, there is only one substance with only two attributes - thinking and extending. These terms "substance" and "attribute" had very specific technical meanings at the time Spinoza wrote, and to further confuse things, he altered these definitions. But the major point for our purpose remains - everything, and every thought that forms the All-that-is, which Spinoza called Nature is inherently related because it is made up of (and motivated, if you will) by the same stuff-Substance.

The implications are clear. Through partaking of the thinking attribute of Substance, we are able to be connected to All-that-is precisely because we share in it; in everything that can exist in space, time, or thought.

Spinoza identifies three distinct ways of knowing in The Ethics. ${ }^{7}$ He calls these three ways of knowing imagination, reason and intuition. Each of these terms is used in a specialized way by Spinoza. We italicize them to illustrate this different usage.

Imagination applies known rules to understand a particular event. This first way of knowing is of particular things either through casual experience or symbols, for example in reading, whereby we conceive of the things we read about. This kind of knowing appears to contain simple observations that are relatively unintermediated by interpretive theories. Spinoza calls this "knowledge of the first kind," "opinion," or imagination. Spinoza wishes to convey unreliability or a hearsay quality because it is confused and not contextualized, an observation subject to interpretation.

Spinoza calls the second way of knowing reason. This is the kind of knowing that derives from an informed understanding of things. It is a theoretical knowledge that, because it is based on generalization, knows the general without knowing the particular.

But intuition, or scientia intuitiva, the third way of knowing, knows both the particular and the general, and does so without the use of reason. It is knowledge gained "from an adequate idea of the formal essence of certain attributes of God to an adequate knowledge of the essence of things" (Shirley, 2002, 267). Spinoza's intuition is an insight showing the relationship that the particular has with the whole. It is our position also that Spinoza's third way of knowing implies a way of being. This is because thinking with "the knowledge of the union which the mind has with the whole of Nature" (Shirley, 2002, 6) not merely describes an actual position of interconnectedness with Being, one that is guaranteed by a Spinozean metaphysics, but enacts a consciousness of it. Such an enacted consciousness brings into play both the thinking and extending aspects of human being. In other words, this knowledge shapes the being of the person differently. It can only occur through a person who not only is in the world in a particular way — Spinoza would say that all of us are - but inhabits it (that is to say, does so knowingly) in this way.

Spinoza's description of the scientia intuitiva is, after all, a curiously self-reflexive phrasing, and Spinoza is not being deliberately circular in stating it this way. Spinoza wrote this passage in The Emendation of the Understanding as a young man. We think he was prophetically outlining the case he would make again and again, 
Whitman-like, throughout his life. It is as though there is something just beyond the edges of knowing that, like Heidegger, he points at, mutely.

Knowledge of this third kind involves understanding correctly the nature of being at the same time as correctly interpreting a perception within this encompassing notion of being. If Spinoza's description is correct, we have to entertain the notion that this kind of knowing is necessarily connected with a different mode of being. In this mode of being, one is literally so allied with All-that-is, that what one is, is composed of All-that-is. The depth of awareness of experience of unity goes beyond merely instrumental knowing. Spinoza appears to be describing going through the world with a pervasive sensibility of the inherent interconnectedness of all things. In some obvious ways we begin to see Spinozean metaphysics and Aboriginal cosmology, as expressed earlier by Michael Paul, come into alignment. During time spent with the Elders one author has often heard reference to, not merely a person, but a deer person, a bear person, a tree person. Here "person", takes the place of "being." In this view, different "persons" appear to be acting as different forms - in Spinoza terms, modes - of All-that-is. The underlying notion of interconnection is expressed in the common noun "person" that is used for all things. This linguistic shift both reflects and shapes a world view that considers different modes of All-that-is as having, if not equal ethical merit, at least an ethical standing. This ethical and ontological standing extends also to the world that we in modern Western culture would not think of as a living one. Thus, the concept of rock is necessarily infused with the notion of its inherent worth or standing as a being. As a mode of being that has some kind of shared composition with oneself, there is always the potential for an interaction with it. Thus, a "spirit rock" is not so very far removed from quotidian modes of thinking and being.

Eco-philosopher Neil Evernden offers a similar view of the possibility of interconnected interpretations of the world in his consideration of a tree not as some thing whose borders show at the outmost silhouetted leaf-edge but as a locus of energy transfer between systems. In the image he offers, a tree is imagined as a medium through which, for example, ground water and air interact through the medium of photosynthesis and respiration.

A tree, we might say, is not so much a thing as a rhythm of exchange, or perhaps a centre of organizational forces. Transpiration induces the upward movement of water and dissolved materials, facilitating an inflow from the soil. If we were aware of this rather than of the appearance of tree-form, we might regard a tree as a centre of a force-field towards which water is drawn.... The bark is not the dog any more than the visually delineated object is the tree. We do not mistake bark for the dog, but we habitually mistake the shape for the tree (Evernden, 1985, 41).

You might say that in both cases Evernden cites it is an error to remain stuck at the level of the bark. Considered in this way, the being of a tree is less object-related and more system-oriented and that ontological category, the distinction between self/ 
other, changes. Being a member of a living system changes the nature of what it is to be a tree from a separate object to a locus within cycles of energy.

Perhaps the only immediately apparent similarity between Spinoza and Heidegger's theorizing is the esotericness of their quite divergent views. Heidegger's theorizing is difficult to encapsulate because it is as methodologically different as it is, cosmologically different from what is commonly practiced in Modwestcult. The subject of his thinking might be deep questioning into the meaning and nature of Being, but, especially as represented in his later works, his mode of thinking itself reflects the subject of inquiry. Substantively, Heideggers's work redressed what he himself thought to be a millennia-old gap in Western philosophy - the question of why there is being at all. Methodologically, he chooses a phenomenological route because his Dasein is a being that fundamentally changes and creates its world through its perceptions. ${ }^{8}$

His later writings reflect Heidegger's attempt to bridge the divide between the instrumental existence that comprises life for most humans and the kind of worldembedded perspective that allows for full contact with Being, and that leads to noninstrumental knowing. In the phase of his later writing that is characterized by poetic and mythical reference. We interpret Heidegger's later work as using the only language that worked, were Dasein to attempt to engage Being.

In Building, Dwelling, Thinking, Heidegger attempts to show the allied interests between self and place. ${ }^{9}$ Referring to the Old High German, the root of bauen, to build, is buan. It means to dwell. A trace of this nuanced loss is still found in Nachbar, neighbour. The Nachbar is the near-dweller not the "near-building." But bauen's import goes deeper than this. It goes even to ich bin, in which bin is the derivate; the "be," itself, is a kind of dwelling. In this etymologically-based argument, for one to be implies that one dwells. "The way in which you are and I am, the manner in which we humans are on the earth, is buan, dwelling. To be a human being means to be in the earth as a mortal. It means to dwell" (Heidegger 1977, 324-325).

But the old word bauen also means "to cherish and protect, to preserve and care for, specifically to till the soil, cultivate the vine. Such building only takes care - it tends the growth that ripens into its fruit of its own accord" ${ }^{10}$ (Heidegger 1977, 325). This building is not as well known to us as the kind of edificial construction is. This kind of building - the building that derives from care interwoven with place, is also inherent, Heidegger claims, in the nature of being a person.

Here we have what appears to be at least one of the transformations required for Dasein to approach Being, as opposed to merely investigate the nature of her own existence. When Dasein investigates her own instrumental relationship with place, she is limited by concern. But when Dasein investigates the world through an approach of something like the compassionate well-being of all the elements, this concern transforms into cherishing and protecting - not for the instrumental value of what lies in the world but because of its inherent value. For Heidegger, in order for Dasein to cherish and protect she must do so through this primordial way of knowing. Similarly, the kind of knowing that Spinoza judges to be most enabling of happiness is the way of knowing in which a person "proceeds from an adequate knowledge of the formal essence of certain attributes of God to and adequate knowledge of 
the essence of things" (Shirley 2002, 267). Both Heidegger and Spinoza describe a way of knowing that is premised on a certain kind of relationship between person and the world, a state of being in the world that we believe is different from that of Modwestcult and might be further clarified if we return to the Aboriginal Elders mentioned earlier.

\section{Returning to the Elders}

Alex Mathias is a member of the Temi-Augama Anishinaabe people. He is the head of his family, and lives semi-traditionally on this family territory. In manner reminiscent of both Spinoza and Heidegger he describes a particular kind of knowing that is available to him at times when he and others visit the sacred site known as ChiskonAbikong, "the place of the rock."

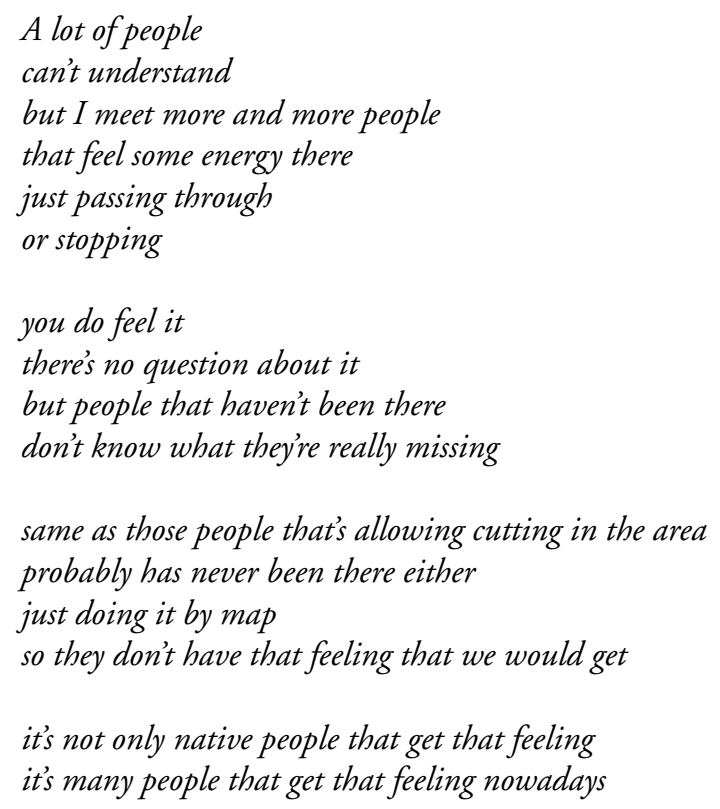

We like these words especially because they evoke the significance of knowing the whole through a particular place, not merely an idea. That is, you have to be in the place to have the feelings that Alex associates with this place. There is no way that those who plan the cutting of forests can understand this merely by looking at the maps of the area. Alex also talks about the kind of knowledge one can have in this particular place:

to see that place

and to feel it

and the messages people can get there 
whether they hear it without voice

or whether they hear it through mind

it's a great feeling because

many peoples' answers are...

people getting answers

maybe not by hearing voices

but in their mind

the answers coming to them

Neither of these passages refer directly to the different state of being we would like to illustrate. Both, however, address a necessary relationship between a place and a person that give a particular and different kind of knowledge or idea. The state that Alex refers to is a listening state, further articulated by Michael Paul, the head of his own traditional family. In this passage, Michael refers to the kind of interaction he has with the place of which he is part:

\author{
you wake up \\ and you have no game plan \\ and you just go out \\ maybe you want to paddle \\ down the lake today \\ or go up the river \\ go down the river \\ but no matter how you feel \\ it's you \\ this land is telling you
what to do
}

This quotation is part of a much longer passage in which Michael Paul speaks of the interactions between the place he calls home and himself, and how each reinforce and contribute to the other. Michael still spends much of his life in the bush as a forest firefighter. What is of interest to us in this passage is how much Michael Paul stays in a listening state when he is "in tune with" the world. In this state, "it's you/this land is telling you/what to do."

This is one of the central qualities, seen in both Spinoza and Heidegger, that inheres in this state of being that we call attentive receptivity. It is a quality of being the surface upon which the co-creative project of being/knowing occurs. What helps to connect these various statements is the kind of life that is lived within and through such thoughts, a life which mirrors the life described by Heidegger's dwelling. Alex 
Mathias grew up trapping and hunting on his family's traditional territory. After a brief period of time living in the modern world, he returned to the land that had been in his family for many generations. Michael Paul considers himself to be one of the last people from the area that has "really lived on the land." Both of these people consider self as defined in conjunction with the place they inhabit and as a result the ideas of both being and knowing are shifted. To be in a state of attentive receptivity is to be in a particular way and to make meaning out of that state. If we are right that this state of being is ontologically different from that which is, for the most part, unconsciously accepted by Modwestcult, then it behooves us as educators to take this into consideration when we have conversations about diversity and act in such a way as to allow that possibility to flourish.

\section{Ontological Diversity and Educative Practice}

We have spent most of the space allotted to us in this paper making the case for a different state of being - one that is ecologically interwoven. Because this is a new kind of claim, we thought it necessary to take some care in making this case. At this point, we would like to connect these ideas to educative practice, but not to attempt to describe what such an educative practice would be. Our argument is this: we suggest that because educative practice does not consider being in the sense we do here in its approach to learning, it does one of its greatest potential disservices to all students, but especially to Aboriginal students. Our research calls for a broader reappraisal of educative practice in modern Western culture on these ontological grounds. How can we make space for the qualities (e.g. openness, interconnectedness, awareness, dwellingness, etc.) of attentive receptivity and allow for this accompanying "third way" of knowing in our classrooms? We suggest that an Indigenous ontology and epistemology will necessarily challenge and benefit the practice of public education as a whole as it comes to recognize the need to consider states of being in learning.

The significance of this research for education is that it identifies state of being as a factor shaping learning. If this is accepted, then public educative practice in modern Western culture must be held accountable for its claims of inclusiveness. If state of being is significant in shaping learning, then we think that public education is obliged to consider it in designing educative practice. By paying attention to the experience of Aboriginal people, public education can better serve them. But it can also better serve other students as well. So the project of Aboriginal education, long seen as an isolated activity, may be directly connected to the revitalization of public educative practice based on ontological principles considered within a wider spectrum of diversity, rooted in a wider ecology. Just what this is in practice will be the subject of a later paper. 


\section{Notes}

1. We prefer Modwestcult for its integral connotation of misguided belief.

2. Critiques of variations on Modwestcult are numerous. See Merchant (1996); Evernden (1985); Bateson (2002).

3. As it happens, the ontological alternative we investigate may also serve to raise the status of other non-human beings.

4. We quote the Elders in poetic form, partly to honour patterns and rhythms of speech. For more reasons see Beeman, (2006), but in brief, this is also to acknowledge what Wade Davis refers to as the poetry of the shaman being replaced by the prose of the priest (personal communication, 2003).

5. Temagami is a large and variously defined region in central Ontario. It is known nowadays for its excellent, rugged, canoeing, combining lake and river travel. It has recently been opened to mineral prospecting. It was also the site of a major clash between environmentalists, Aboriginal people and logging and corporate interests, two decades ago, and this conflict continues in less public forms to this day. The conflict is over the cutting of ancient forests.

In this paper, we quote two elders from the Teme Augama Anishinaabe. Alex Mathias is an elder who has moved from Bear Island to his family's traditional land. There he lives semitraditionally. I met Michael and Leo Paul through Alex. Michael is now traditional head of the Paul family, one of the fourteen original families in the Temagami region.

Chance brought me to Alex's one summer. Alex, his wife and spiritual partner, MaryCarol and I spent that afternoon in conversation. Alex shared with me his concern about how Western education was poorly serving the interests of his people. Later, in thanks, I sent him a documentary film that I and three others had collectively directed and produced that explored this and other issues in the context of theories of development relating to Ladakh.

The next summer, I returned to make a long solo canoe journey that would mark a change in my position with respect to the natural world. I stopped in at Alex's at his request. He and Mary-Carol presented me with an idea for a documentary film that would tell the story of a sacred site under Alex's care which was threatened by proposed clear-cut forestry operations. They requested my help in making it. I left for my solo trip, concerned that to help with this project would put my own doctoral research in jeopardy. The journey was successful, but the success I experienced, predicated as it was on an intact more-than-human world, convinced me to agree to the request Alex and Mary-Carol had made. So, for the next year, I moved my research slightly to the side of my desk as I made this film to help protect the sacred site.

During this time, Alex and I became friends, the threat of logging increased, and MaryCarol passed on. I attribute our friendship to the facts that I was willing to both sincerely attempt to understand and represent Alex's position to a wider audience, that I worked for no monetary recompense, and that I was interested in the broader issues that this task opened. Alex freely shared his stories with me, as did other elders such as Michael and Leo Paul, initially to make the film, but later, out of interest. The result was Daki Menan, which has served to represent the ideas of Alex, other elders, and Western environmentalists, regarding the sacred site called Chiskon-abikong; Place-of-the-rock. The words quoted in this paper come from interviews made in preparation for this film. While the quoted segments do not all appear in the film, they centre on the relationship between people and the world-nothuman. This has become the focus of my intellectual work, as I reflect on the generously shared words and stories of the elders with whom I worked to try to make sense of my own culture's position.

6. The name we give to the primary mode of being in Modwestcult is homo mobilis - the busy moving disconnected person, never responsible to the place she comes from because she 
is never there long enough to face the consequences of her actions. She acts in individualistic, competitive, acquisitive, selfish, egotistical and irresponsible ways. These characteristics are seen as desirable in Modwestcult.

7. This contrasts with his earlier design of four kinds of knowing, expressed in Emendation of the Understanding.

8. The relationship to Merleau-Ponty's thought is evident. Perceivers can have no reliable objective point of reference because the very shape of their being is a contributing feature of their perceptions. Heidegger's response is, instead of looking with Descartes or Plato for an external point of reference or certainty, to espouse, instead, the flexibility of circumstance and to make the Dasein itself, its own reference point.

9. To those unfamiliar with it, one of Heidegger's main forms of argumentation, that Steiner calls etymological, can be disconcerting. Our interpretation is that Heidegger is not attempting proof. He is rather opening possibility. To require certainty in reading him is like putting too much of your weight on any stone in a stream crossing. You only have the chance of making it to the other side if you trust each rock just enough. It is your prerogative to trust the footing completely once the other side has been reached.

10. The term "cherish" is often the translation for the relationship between Anishinaabe people and the place they inhabit. This is not merely the existing relationship, but the desired relationship.

\section{References}

Abram, D. (1997). The Spell of the Sensuous: Perception and Language in a More-than-Human World. New York: Random House.

Bateson, Gregory. (1972). Steps to an Ecology of Mind. New York: Ballantyne.

Beeman, C. (2004). Daki Menan. (Documentary film, 22 minutes). Temagami and Kingston: Daki Menan Productions.

Beeman, C. (2006). Another Way of Knowing and Being. Unpublished Doctoral Thesis, Queen's University, Kingston.

Davis, Wade. (1996). One River: Explorations and Discoveries in the Amazon Rain Forest. New York: Simon and Schuster.

Evernden, N. (1993). The Natural Alien. (Second Edition). Toronto: University of Toronto Press.

Heidegger, M. (1977). Basic Writings. David Krell, (Ed). New York: Harper and Row.

Heidegger, M. (1962). Being and Time. J. Macquarrie and E. Robinson, translators. New York: Harper and Row.

Merchant, C. (1996). Earthcare: Women and the Environment. New York: Routledge.

Noddings, N. and Shore, P. (1984). Awakening the Inner Eye. New York and London: Teachers College Press.

Rowe, S. (2002). Home Place: Essays on Ecology. Edmonton, Alberta: Newest Press.

Shirley, S. and Morgan, M. (2002). Spinoza: Complete Works. Indianapolis, Cambridge: Hackett Publishing Company. 